\title{
Science, Revolution, and Monarchy in Two Letters of Joseph Donath to František Antonín Steinský
}

\author{
JONATHAN SINGERTON
}

A surviving collection of letters addressed to the Bohemian academic František Antonín Steinský (1752-1816) contains a number of interesting correspondents. ${ }^{1}$ Among twenty-two letters, one finds a diverse array of important intellectuals of the eighteenth century. These include Father Antonio Piaggio, the Vatican's conservator of ancient manuscripts who was among the first to study the papyri discovered in the ruins of Herculaneum near Naples; Karl Heinrich Seibt, one of the leading academics and Catholic theologians in Prague; and Karel Rafael Ungar, the Premonstratensian antiquarian and librarian. ${ }^{2}$ It is fitting, after all, since Steinský took great pride in corresponding and meeting many of the luminaries of his day. The most famous author within this collection is the polymath American revolutionary Benjamin Franklin, whom Steinský met during a trip to Paris in $1781 .{ }^{3}$ Franklin was well-known in Europe as the inventor of the lightening rod and his role as a representative of the revolutionary American republic increased his celebrity at this time. ${ }^{4}$ Franklin's two letters contained in the collection gained attention as early as 1905 when Steinskýs own letters to Franklin became known among American scholars. Subsequent investigations between American, Austrian, and Czech academics led to the realization of the transatlantic connection between Prague and Philadelphia in the late eighteenth century. ${ }^{5}$

1 Literární archiv Památníku národního písemnictví (LA PNP), Fr. S. A. Steinský (1760-1811). For this collection, see Alena PetráŇovÁ, Z korespondence Františka Steinského, proního profesora pomocných véd historických na Karlově universitè, Acta Universitatis Carolinae 2, 1958, pp. 101-112; František BAŤHA, Fragment literárni pozůstalosti Fr. Ant. Steinského, Praha 1960, pp. 1-2.

2 LA PNP, Fr. S. A. Steinský, Seibt to Steinsky, 27 April 1780 and 3 August 1781.

3 Barbara B. Oвеrg, The Papers of Benjamin Franklin 34, New Haven-London 1998, p. 316.

4 Rudolf KolomÝ, Benjamin Franklin (1706-1790) a jeho přinos k nauce o elektřinè, Pokroky matematiky, fyziky a astronomie 48, 2003, pp. 129-142; Josef PoLIšEnskŕ, Benjamin Franklin, američtí Moravané a čeští čtenáríi, Praha 1972, pp. 315-322; IDEM, Benjamin Franklin a proni americká revoluce, Praha 1956.

5 The first scholar to note Steinsky's correspondence contained within the Franklin papers was Albert Smith who contacted Julius Wiesner, professor of botany at the University of Vienna in 1905. Wiesner, who championed the figure of Jan Ingenhousz (1730-1799) and knew of Ingenhousz's close contacts with Franklin, entrusted the further investigation of Steinsky's connection with Franklin to Albín Bráf and Čeněk Zíbrt. The pair correctly identified Steinsky as the author and receipt of Franklin's correspondence in Philadelphia but failed to find the Franklin correspondence contained 


\section{/ EDITIONS AND DOCUMENTS/}

Yet one correspondent within this collection who is little acknowledged and about whom relatively little has been revealed is the Bohemian merchant Joseph Donath (1751-1829). ${ }^{6}$ Donath shared a deep friendship with Steinský stemming from his education at the Charles University in Prague where he likely met Steinský for the first time in the mid-1770s. ${ }^{7}$ After Donath relocated to Philadelphia in the early 1780s, the pair continued their friendship and Donath visited Steinský during his only return visit to Prague in $1789 .^{8}$

The five existing letters sent from Donath to Steinsky from the United States are extremely valuable and unique sources of contrasting opinions on politics between Central Europe and North America as well as revealing evidence of the international collaboration over scientific inquiry in the late eighteenth century. Moreover, the contents of two particular letters are striking examples of the altered opinion of Donath about his former homeland and its system of government once he had settled in the United States. His letters of 19 April 1790 and 20 July 1792 make clear his thoughts on monarchy and how it contrasted the spirit of republicanism experienced by the inhabitants of the United States. Donath's frankness and cheeky indirect tone with Steinský underline his serious critique of the Habsburg regime from an emigrant's point of view. It forms an interesting but unnoticed connection between the Czech lands and the United States. ${ }^{9}$ These letters, presented in an edited form for the first time below, also reveal the web of social and commercial transatlantic ties in Central Europe at the end of the eighteenth century. Before clarifying the contents of the letters and presenting the short edition, it is necessary to detail the biographies of both the author and recipient and to explain why and how Donath found himself in the United States and writing to his friend in the 1790s.

in the Literary Archive in Prague. This collection only came to light in 1921 and the importance of the Franklin letters appeared in national and international newspapers. A cutting can be found in the collection today.

6 The most detailed previous assessment of the correspondence between Donath and Steinský is A. Petráňová, Z korespondence Františka Steinskébo, pp. 103-105. Petráňová also posits that the collection came to the LA PNP from Josef Karel Burde (1779-1848), son of the engraver Jan Karl Burde (1744-1815) whom Steinský knew personally.

7 Three items relating to Donath's study at the Charles University in Prague are found in the University of Pennsylvania Archives, Kislak Center for Special Collections, Misc. Manuscripts, Joseph Donath Manuscripts, Documents related to Donath's attendance of the University of Prague 1772-1777. See also Ivan HLAvÁčex, Přehledné dẽjiny pomocných véd historických v českých zemich ze zvláštním zrètelem ke stolici oboru na filozofické fakultě Univerzity Karlovy, in: 200 let pomocných věd bistorických na Filozofické fakultè Univerzity Karlovy v Praze, Praha 1988, p. 29.

8 Library of the American Philosophical Society (APS), Franklin Papers, Mss.B.F85, Part 9, XXXVI, p. 142, Steinský to Franklin, 17 June 1789.

9 Marek VLHA, „What is the Bohemian nation?" Geneze povédomi o českém národu ve Spojených státech amerických do počátku 20. století, Český časopis historický 113, 2015, pp. 381-414. 


\section{František Antonín Steinský}

The character and career of František Antonín Steinský is not widely known outside of a few select studies. ${ }^{10}$ In spite of this, Steinský is an important figure within the Bohemian Enlightenment and the wider network of eighteenth-century intellectuals known as the Republic of Letters. ${ }^{11}$ Steinskýs life revolved around the intellectual circles of Prague. After his upbringing in Litoměřice, he became a skilled draughtsman and semi-professional painter. He began teaching technical drawing at the Imperial and Royal Normal School in Prague's Malá Strana district from $1775 .{ }^{12}$ The Normal School grew out of the Theresan education reforms to enable compulsory schooling for all children in the Habsburg Monarchy between the ages of six and thirteen. ${ }^{13}$ Steinský remained at this school until 1810 when he became the dean of the philosophical faculty at the Charles University where he had lectured on an interim basis from 1784. Whilst his university career was dogged by complaints from his peers and accusations of tedious lectures from his students, his time at the Normal School was much better spent. ${ }^{14}$

At the Normal School, Steinský instructed four levels of pupils in drawing and calligraphy but also devoted himself to publishing pedagogical texts. ${ }^{15}$ Publications by educational staff provided a steady revenue stream for eighteenth-century schools in the Habsburg Monarchy. The Normal School at Prague was one of nine normal schools to receive a printing license during this period. ${ }^{16}$ Steinský published a large array of various texts during his lifetime. He prepared several handbooks for pupils on illustration and calligraphy. ${ }^{17}$ His wider oeuvre ranged from his editions of devotional music such as

10 František BAŤHA, František Antonin Steinský (1752-1816), in: Heribert Sturm (ed.), Biographisches Lexikon zur Geschichte der böhmischen Länder, vol. 4. Lieferung 4, München 2011, p. 285 and entry „Steinsky, Franz Anton“ in Constantin von Wurzbach (ed.), Biographisches Lexikon des Kaiserthums Österreich 38, Wien 1879, p. 167.

11 For recent accounts of the Bohemian Enlightenment and the Republic of Letters, see Ivo CERman - Rita Krueger - Susan Reynolds (edd.), The Enlightenment in Bohemia: Religion, Morality, and Multiculturalism, Oxford 2011; Howard Hotson - Thomas Wallnig (edd.), Reassembling the Republic of Letters in the Digital Age: Standards, Systems, Scholarship, Göttingen 2019, pp. 315-342.

12 Aleš Vincenc PAŘízeк, Ausführliche Beschreibung der am 15. November 1800 gehaltenen Jubelfeyer der k.k. Normalschule in Prag, nebst einer kurzen 25jährigen Geschichte dieser Schule, Prague 1801, pp. 57-58.

13 James van Horn Melton, Absolutism and the Eighteenth-Century Origins of Compulsory Schooling in Prussia and Austria, Cambridge 1988, pp. 200-204, 214-217.

14 A. Petráňová, Z korespondence Františka Steinského, p. 108.

15 Anton WeIss, Geschichte der theresianischen Schulreform in Böhmen, Wien 1906, xviii and 4.

16 J. van Horn Melton, Absolutism and Compulsory Schooling, p. 219.

17 A. Weiss, Geschichte, p. 185. Steinskýs calligraphic models contrasted the prevailing norms of the Viennese school of instruction, see Ivan HLAvÁčE - Jaroslav KAšPAR, - Rostislav NovÝ, Vademecum pomocných věd historických, Jinočany 2002, p. 87; Angelika Plank, Akademischer und schulischer Elementarzeichenunterricht im 18. Jahrhundert, Wien 1999, pp. 172-179; Gerhard Pichler, Das 
the Lieder zur öfentlichen und häuslichen Andacht (1783) to works on natural history and geography textbooks designed for general school use. ${ }^{18}$ His songbook aimed to instill the practice of religious worship and Christian praise among the pupils of the Normal School. ${ }^{19}$ His tireless energy exercised by publishing and compiling the hymns earned him a $100 f$ reward by the school directorate. ${ }^{20}$

Steinsky's literary output reflected his standing among the intellectual circles of eighteenth-century Bohemia. He knew personally the mineralogist Ignaz von Born who pioneered the new method of extracting precious metals by amalgamation. ${ }^{21}$ In the 1770 s, Born founded an informal society of Bohemian thinkers and noblemen called the Böhmische Gelehrte Privatgesellschaft, the forerunner of the Royal Bohemian Society of Sciences and the Czech Academy of Sciences today. ${ }^{22}$ Steinsky claimed membership of this association and contributed an essay to the society's journal on an ancient coin enclosed in stone thirty feet deep and discovered during the construction of a fortress in Terezín. He used this example to demonstrate his ideas about the formation of the Earth's mantle through a process of sedimentation. ${ }^{23}$ Steinský also contributed an article on the development of the Normal School to Isaak Iselin's (1728-1782) Ephemeriden der Menschbeit. ${ }^{24}$ At the same time, he contributed to the growing literary activities in the Bohemian Enlightenment. As editor of twelve volumes of the periodical Monatliche Beyträge zur Bildung und Unterhaltung des Bürgers und Landmannes, Steinský

Studienwesen des Erzherzogtums unter der Enns (Wien und Niederösterreich) 1740-1870 II, Frankfurt am Main 1981, p. 532; Renate Seebauer, Lebrerbildung in Porträts: Von der Normalschule bis zur Gegenwart, Berlin-Wien 2011, pp. 23-24.

18 [F. A. Steinsky] - die k.k. Normalschuldirektion, Lieder zur öffentlichen und häuslichen Andacht mit Melodien größtentheils von den besten vaterländischen Meistern, Prag 1783; [F. A. STEInsky], Anleitung zur richtigen Erkenntniß der merkwürdigsten natürlichen Dinge, Wien 1780; IDEM, Erdbeschreibung für österreichische Schulen, Wien 1783.

19 V. Pařízen, Ausführliche Beschreibung, p. 61; Joseph Alexander von Helfert, Die österreichische Volksschule: Geschichte, System, Statistik I. Die Gründung der österreichischen Volksschule durch Maria Theresia, Wien 1860, p. 416; A. WeIss, Geschichte, p. 17.

20 A. WeIss, Geschichte, p. 65.

21 Mikuláš TEICH, Born's amalgamation process and the international metallurgic gathering at Skleno in 1786, Annals of Science 32, 1975, pp. 305-340.

22 Josef Haubelt, Born und Böbmen, in: Helmut Reinalter (ed.), Die Aufklärung in Österreich: Ignaz von Born und seine Zeit, Frankfurt am Main 1991, pp. 99-116.

23 František Antonín STeinský, Schreiben an den Herrn Hofrath von Born über eine in Stein gefundene Münze, nebst einigen dadurch veranlaßten Gedanken über die Entstehung der gegenwärtigen Oberfäche der Erde, Abhandlungen einer Privatgesellschaft in Böhmen, zur Aufnahme der Mathematik, der Vaterländischen Geschichte, und der Naturgeschichte 7, 1784, pp. 377-397.

24 IDEM, Von dem Fortgange des Normalschulwesens in Böhmen, in: Ephemeriden der Menschheit oder Bibliothek der Sittenlehre, der Politik und der Gesetzgebung II, Leipzig 1784, pp. 231-236. 
was at the forefront of knowledge production in the Bohemian capital and aimed to disseminate new learning beyond the non-aristocratic classes..$^{25}$

Steinský also affiliated himself with powerful people in Bohemia. His celebratory address of the consecration of Ferdinand Kindermann von Schulstein as the Bishop of Litoměřice in 1790 - of which a manuscript copy exists in the Steinský collection at the Literary Archive of the National Museum of Literature - came about as a result of their close friendship and collaboration on education matters. ${ }^{26}$ Kindermann was the head of the Bohemian educational commission as part of the Theresan reforms and responsible for overseeing the compulsory schooling agenda in the region. It was thanks to Bishop Kindermann's support that Steinský successfully applied for a royal grant to travel to western Europe in $1780 .{ }^{27}$ Steinskýs tour of England, the Dutch Republic, France, Switzerland, and the Italian peninsula took place between mid-1780 and mid-1781. His reason for travelling through Europe was to examine the models of female education for the founding of a new institution in Prague..$^{28} \mathrm{He}$ gained temporary leave of his duties at the Normal School and Father Aleš Vincenc Pařizek assumed his teaching for the academic year. ${ }^{29}$ When Steinský returned to Prague, he compiled a report on his observations of female education throughout his tour of western Europe and recommended a universal state education for girls in history, geography, crafts, and the arts. ${ }^{30}$ His contacts abroad welcomed his enquiries and the friendships formed during his visits to major centres of European learning lasted throughout his lifetime. It is these contacts such as Antonio Piaggio in Naples and Gabriel Brunelli (1728-1797), professor of botany in Bologna, who appear in Steinskýs epistolary collection in the Literary Archive of the National Museum today. Steinskýs most notable acquaintance in this period was

25 IDEM, Monatliche Beyträge zur Bildung und Unterhaltung des Bürgers und Landmanns I-II, Prag 1784-1789; Norbert Angermann, Die erste böhmische Zeitschrift für den Landmann, in: Dan Berindei - Heinz Ischreyt (edd.), Der Bauer Mittel- und Osteuropas im sozioökonomischen Wandel des 18. und 19. Jahrhunderts: Beiträge zu seiner Lage und deren Widerspiegelung in der zeitgenössischen Publizistik und Literatur, Wien-Köln 1973, pp. 275-280.

26 František Antonín Steınskŕ, Inauguratio domini Ferdinandi equitis a Schulstein, dei et apostolica sedis gratia Episcopi Litomericensis, Prague 1791.

27 A. Petráñová, Z korespondence Františka Steinskébo, p. 107.

28 R. KolomÝ, Benjamin Franklin (1706-1790) a jeho př́nos k nauce o elektřinè, p. 132.

29 A. Weiss, Geschichte, p. 28; Aleš Vincenc PAর̌ízek, Ausführliche Beschreibung der am 15. November 1800 gehaltenen Jubelfeyer der k.k. Normalschule in Prag, nebst einer kurzen 25jährigen Geschichte dieser Schule, Prag 1801, p. 62.

30 František Antonín STEINskÝ, Allgemeine Beobachtungen über das Erziehungswesen des weiblichen Geschlechts bei Gelegenheit einer Reise durch die Schweiz, Holland, England, Frankreich und Italien, auf Befehl wailand Ibrer Majestät Maria Theresia niedergeschrieben [1784?]. Steinský announced the text but no copy seems to have survived, see A. Weiss, Geschichte, p. 157; A. Petráñová, Z korespondence, pp. 107-108. 
Franklin, whom he sent various scientific books and presented a Bohemian textile as a gift after he returned home to Prague. ${ }^{31}$ Steinskýs international correspondence and familiarity with leading intellectuals across Europe created a wider dynamic within the Bohemian Enlightenment.

In October 1784 Steinský became the first professor of auxiliary historical sciences at Charles University in Prague. He lectured on the basics of diplomacy and heraldry for the first-year students of the law and philosophy faculties and on antiquity, which included chronology, mythology, geography and numismatics, for second-year pupils. Students decried the tedium of his lectures and, perhaps needing a diversion, Steinský encouraged travel among his students and took them to explore the ruins of castles near Prague. ${ }^{32}$ Steinský struggled with the unpopularity of his lectures throughout and returned to teaching calligraphy and history at the Normal School at the same time. ${ }^{33}$ Despite his poor reputation, Steinský continued as a professor at the university until his death in 1816 when he was succeeded by Jan Helbling of Hirzenfeld.

\section{The Merchant Joseph Donath}

Joseph Donath is less well known than Steinský. As a merchant he did not leave behind a trail of literary works. He has not been the subject of a thorough historical investigation before now. Donath died in Philadelphia, but he was born in St. Georgenthal (nowadays Jiřetín pod Jedlovou) in northern Bohemia in early 1751. His parents Anton Donath and Anna Catharina Hübner were of modest means. One of his four brothers became a local church painter. In the early 1770s, he studied at the Charles University in Prague. ${ }^{34}$ It is during this period that he likely met Steinský for the first time. Little else is known about his early years until his relocation to Vienna by the early 1780s. Around this time, Donath joined the freemason lodge Zur wahren Eintracht, which ingratiated him into the intellectual circles of Mozart and Born who also attended this lodge. ${ }^{35}$ This social milieu in Vienna eventually made Donath well-placed for his mercantile career in the United States.

31 Steinský to Franklin, 12 September 1781 in: Barbara B. OвеRg (ed.), The Papers of Benjamin Franklin (PBF), 35, New Haven 1999, pp. 468-470 and 3 August 1783 in: Ellen R. Cohn, PBF 40, New Haven 2011, pp. 429-433.

32 Marcela Kalašová, Fenomén putování po bradních zřiceninách v proní polovinè 19. století. Edice a obsahový rozbor trí cestovnich deníkủ Karla Krameria, Praha 2009 (Dissertation), p. 9.

33 A. Petráňová, Z korespondence, p. 110.

34 University of Pennsylvania Archives, Kislak Center for Special Collections, Misc. Manuscripts, Joseph Donath Manuscripts.

35 Haus-, Hof- und Staatsarchiv Wien, Kabinettsarchiv, Vertrauliche Akten, K. 70, Nos. 4 \& 5, 8 and 13 July 1783, fol. 52-57. 
Central to Donath's relocation to the United States were the effects of the American Revolution upon the Bohemian lands. The revolutionary upheaval in the thirteen mainland British North American colonies precipitated new economic opportunities among European merchants. American independence broke the British monopoly on colonial goods from the former thirteen colonies. Proponents of the self-proclaimed United States of America declared their ports open for international commerce. Merchants in the Habsburg Monarchy were as assiduous to this change as other observers were across Europe. In August 1776 - one month after the publication of the Declaration of American Independence - the captain of a local infantry regiment in Trieste noted how the independence of the United States merited „considerable attention“" as it offered local merchants there a chance to become "rich and respectable. " ${ }^{6}$ The clamour for American commerce defined in many ways the earliest reactions to American independence within the Habsburg Monarchy.

In 1783, a peaceful conclusion to the War of American Independence became a political reality. British and American negotiators agreed to preliminary articles of peace at the end of 1782, paving the way for a formal peace settlement. In anticipation of the end of hostilities, merchants and governments across Europe began manoeuvres to ensure the continuation or expansion of economic interests within the Atlantic markets. Some nations, like the French and Dutch, held a significant head start with treaties of commerce with the Americans allowing their traders an advantage over others through the reduction of tariffs and mutually favourable conditions. Merchants in the Habsburg Monarchy, especially in the ports of Ostend and Trieste, were well positioned at first to compete for a share in American profits. During the American Revolution, Ostend had become an entrepôt of Atlantic trade thanks to the neutrality of the Austrian naval ensign and the same neutrality had allowed Triestine merchants to conduct the first tentative direct voyages to North American ports from 1782 onwards. ${ }^{37}$

Habsburg officials in Vienna agreed to establish a representative in the United States in early 1783 . The new representative would not carry any official diplomatic credentials, however, due to the ongoing peace talks and out of a strict adherence to the norms of diplomatic precedence. Instead, the Habsburg Monarchy's representative in Philadelphia would act in a purely private and commercial manner. Handling mercantile matters related to imperial commerce in America as well as reporting on new economic

36 Finanz- und Hofkammerarchiv, Neue Hofkammer, Kommerz Abteilung, Noten, K. 616, Christoph Beller to the Aulic Chamber (Hofkammer), 7 August 1776, fol. 365-367.

37 Jonathan Singerton, New World, New Market: A Merchant's Mission to Trade between Philadelphia and Trieste in 1783, Yearbook of the Society for $18^{\text {th }}$ Century Studies on South-eastern Europe 1, 2018, pp. 65-72. 
opportunities in the Atlantic were the two major occupations for this position. ${ }^{38}$ The insistence for such an individual had come from the regional administration in Brussels in the Austrian Netherlands since American commerce mattered greatly to the mercantile community centred around Ostend. Initial instructions and designs for this mission came from the commercial council in Brussels with the recommendation of the Minister Plenipotentiary Prince Georg Adam von Starhemberg who had supported transatlantic ventures throughout the War of American Independence. ${ }^{39}$ Starhemberg and his advisors even proffered a candidate for the mission to their Viennese superiors: Baron Frederick Eugene de Beelen-Bertholff, an experienced bureaucrat in the Brussels administration who had served as secretary in the Council of Finance. ${ }^{40}$ Viennese officials such as the State Chancellor Prince Wenzel Anton von Kaunitz-Rietberg were uneasy with the selection of Beelen as the emperor's official representative in the United States, however. Concerns focused on his background in the Austrian Netherlands and questions arose over his loyalty to represent the whole of the Habsburg Monarchy's interests. Although Kaunitz harboured these doubts, he nevertheless acquiesced to the nomination of Beelen as the Imperial Counsellor of Commerce and Navigation in the United States' following the emperor's approval in March 1783. After further negotiations between the constituent parts of the Monarchy and preparation in Brussels, Beelen subsequently arrived in Philadelphia in September 1783 along with his family and secretary. He would serve in this capacity until 1789 when the failure to achieve a treaty of commerce with the Americans and the outbreak of the French Revolution undermined any reason for the Habsburgs to compete for American commerce.

Misgivings about Beelen's official status were common among the merchant community in the Habsburg lands. Company directors resorted to sending their own trusted and appointed representatives instead who would act as a point of connection in the United States. By 1785, at least three private representatives acting on behalf of firms in the Habsburg Monarchy were active in the United States in order to overcome problems of distance, reliability, and the perceived lack of information or trustworthy contacts in

38 This episode is discussed in my forthcoming book IDEM, The American Revolution and the Habsburg Monarchy, Charlottesville-London 2021. See also IDEM, A Story of Benign Neglect? Die Gründungsgeschichte Amerikas und die Habsburgermonarchie 1776-1783, Opera historica 17, 2016, pp. $56-68$.

39 The British envoy in Brussels, William Gordon accused Starhemberg of being a "well-wisher“ to the American rebels, see Gordon to the Earl of Suffolk, 27 April 1776, The National Archives at Kew, State Papers 77/108.

40 Edward A. Mallon, Frederick Eugene, Baron de Beelen-Bertholff, Records of the American Catholic Historical Society of Philadelphia 59, 1948, pp. 148-152; Jonathan Singerton, 175 Years or 235 Years of Austrian-American Relations? Reflections and Repercussions for the Modern Day, in: Joshua Parker - Ralph Poole (edd.), Austria and America: 20 $0^{\text {th }}$-Century Cross-Cultural Connections, Zurich 2017,pp. 13-30. 
American markets (including Beelen). ${ }^{41}$ Joseph Donath acted as one of these representatives. His employer was Joseph Paul von Weinbrenner, an enterprising man who ran a large warehousing business in Vienna and had ideas for the expansion and improvement of Austrian trade. ${ }^{42}$ Weinbrenner sought to export Austrian products via Trieste to the United States in exchange for furs, tobacco, and sugar. ${ }^{43} \mathrm{He}$ enlisted the support of Kaunitz as well as Jan Ingenhousz, the Dutch scientist and court physician who was a close friend of Benjamin Franklin's in Vienna, to realise his goal and to obtain letters of introduction for American merchants. ${ }^{44}$ Determined to make a success of his venture, Weinbrenner chose Donath as his private representative in the United States. Donath left Vienna in early August and arrived in Philadelphia a few months after the Beelen family in December 1783.

Donath's initial responsibilities in the United States centred around testing the sale of certain wares and procuring American products. He carried with him samples of Weinbrenner's stock consisting of various types of shoes, hats, fabrics, and Bohemian glassware. He intended to either sell these for profit or exchange them direct for furs, the main product desired by Weinbrenner. North American furs enjoyed a certain popularity in Vienna stretching back to the seventeenth century. Coveted as a mark of luxury, these furs had come only indirectly to Austrian customers who paid a high premium. ${ }^{45}$ The opportunity to acquire furs directly in North America was a lucrative prospect. Confident of the task before him, Donath quickly established a business on the corner of Chestnut Street to showcase and offer his array of Central European goods.

Donath failed to strike up a cordial relationship with Beelen who felt spurned by his presence in the city as it eroded his authority as the representative of all imperial subjects in the United States. The two men met in person sometime before April 1784. Beelen described him as an „intelligent man“ but thought Donath would not succeed in business in Philadelphia. He noted the paltry payment Donath received from Weinbrenner who expected that Donath would also travel to New York and Boston within

41 Pierre Cailleau arrived in Philadelphia from Antwerp on behalf of the Flemish firm Werbrouck \& Mellerio. John Paterson represented the Ostend firm Herries, Keith $\mathcal{G}^{2}$ Co. in Charleston. Filippo Filicchi supervised the interests of the Livornese firm Salucci E Figlio in New York, Philadelphia, Boston and Providence.

42 Karl Pribram, Geschichte der österreichischen Gewerbepolitik von 1740 bis 1860, Leipzig 1907, p. 79, 205; Herbert Matis, Die Schwarzenberg-Bank. Kapitalbildung und Industriefinanzierung in den habsburgischen Erblanden 1787-1830, Wien 2005, pp. 24-25.

43 Quoted in PBF 39, Ingenhousz to Franklin, 26 February 1783, pp. 188-189.

44 Ingenhousz to Franklin, 8 April 1783, PBF 39, pp. 444-446.

45 Veronika Hyden-Hanscho, Invisible Globalization: French Hats in Habsburg Vienna, 1650-1750, Journal of European Economic History 43, 2016, no. 3, pp. 11-54. 
a two-year period. ${ }^{46}$ Beelen, however, did his best to advise Donath, especially concerning the prospects for obtaining furs from Native Americans in upper New York State. Donath reciprocated by sharing with Beelen his prospectus of samples from Weinbrenner's inventory. He even gifted him a catalogue of fabrics stocked by Weinbrenner which Beelen dutifully forwarded to his superiors in Brussels, noting how „our Flemish fabric merchants might find them useful when deciding their cargoes for America. " ${ }^{47}$ Donath absorbed Beelen's observations on the Oneida nation in particular and planned an expedition to their lands for the summer of 1784. Little information remains about Donath's travels in the United States or his dealings with the Native Americans. Yet his trip must have had some success as he later planned further commercial journeys to Fort Pitt and Fort Detroit in the American Midwest.

Donath's mission on behalf of Weinbrenner's firm in the United States ended in 1785. Facing the prospect of returning to the Habsburg Monarchy, Donath balked. It is uncertain exactly how he refused to return, but looking at his situation it is clear to see why Donath chose to remain in the United States. For the last two years, he invested considerable energy into forming a new and lucrative business, namely procuring discount furs by selling fashionable Bohemian goods. It is unlikely Donath wanted to give up this hard-earned business or his freer life in the United States.

Instead of returning to the Habsburg lands, Donath settled in Philadelphia permanently. Around 1786 he founded his own commercial business in Philadelphia, Donath E Co., which specialized in Bohemian goods such as textiles and glassware. Over the next few decades, Donath's new business thrived and he formed many long-lasting contacts among the elite of American society. He provided both Franklin and Thomas Jefferson with Hungarian wines. ${ }^{48}$ Jefferson also relied on Donath to procure the best Bohemian window-glass for the large cupola of his home at Monticello. ${ }^{49}$ Donath also dabbled in producing honey, purchasing twenty-four beehives in March 1787 and setting up an amateur apiary at Spring Mill outside Philadelphia. ${ }^{50}$ Although his honey

46 Beelen's report dated 25 April 1784, Haus-, Hof- und Staatsarchiv, Belgien, DDB Rot, K. 182a, Add. P, fol. 65-66.

47 IвIDEM, fol. 65.

48 APS, Franklin Papers, Mss.B.F85, Part 8, XXXIV, p. 161, Joseph Donath to Franklin, 27 October 1786; Csaba LÉvaI, „The Tokay is Much More Superior to What You Sent Me Last Year Under That Name"- Thomas Jefferson and his Hungarian Wines, Hungarian Review 6, 2002, no. 6, pp. 74-84.

49 Jefferson preferred Bohemian glass for its „stout“ quality which suited the exposed hill-top location of Monticello, see Jefferson to Donath, 4 December 1796, in Barbara B. OBerg (ed.), The Papers of Thomas Jefferson 29, Princeton 2002, pp. 212-213.

50 Donath's Journal of Beekeeping at Spring Mill is preserved at at the Library of the American Philosophical Society, see Jonathan Singerton, The APS and Central Europe: A Bumbling Beekeeper from Bohemia, 25 May 2018 via https://www.amphilsoc.org/blog/aps-and-central-europe-bumbling-beekeeper-bohemia [last accessed 28/05/2021]. 
scheme failed within a few years, Donath proved to be a remarkably successful merchant in Philadelphia. His business Donath $\mathcal{F}^{2}$ Co. continued trading between Central Europe and North America for decades to come.

Donath's new life in the United States did not dislocate him from his former homeland, however. He made a return visit in around 1789, for example, when he met with Steinský and collected a number of papers and books to deliver on his behalf to Franklin. ${ }^{51} \mathrm{He}$ also maintained many contacts in Bohemia in addition to Steinský, and it appears that Donath's marriage formed part of these transatlantic bonds. His betrothal to Maria Rosalia Janke (1772-1850) strengthened his economic ties with the Janke family of Skalica (Langenau) near Nový Bor (Haida). ${ }^{52}$ The Janke family were key exporters of Bohemian glassware for decades and the region around Nový Bor was an important centre for glass production. ${ }^{53}$ Maria Rosalina Janke's uncle was Jan Vaclav Janke whom Donath referred to in his letters to Steinský as his provider of Bohemian goblets. ${ }^{54} \mathrm{In}$ other letters, Donath requested Steinský to help arrange some of their transactions and help with information on shipments between Nový Bor and Philadelphia. It is also clear Donath intended to return to Bohemia in 1794 but instead awaited the arrival of his wife and a chaperone in the United States. ${ }^{55}$ A paper fan gifted to Maria Rosalia either from her brother or father in 1809 reveals the painful separation still felt many years later between her and her family. ${ }^{56}$ It was, however, a happy marriage between Joseph and Rosalia Donath. „It is sweet, not to be alone in the world," Donath informed Steinský after telling of his loving new bride. ${ }^{57}$ Together they had two children: Joseph Donath Jr. (1797-1816) and Maria Madelaine Catharine Louisa Donath (1799-1840), who married into the Koecker family of Philadelphia. There exists a sumptuous painting of her upon marriage to Leonard Koecker. Donath's first grandson, Joseph Donath Koecker (1820-1889) became one of the leading architects in the city. Donath himself died

51 APS, Franklin Papers, Part 9, XXXVI, Steinský to Franklin, 17 June 1789, p. 142.

52 Confirmation by Johann Wenzel Helzel that he held a marriage contract back in Bohemia in 1796 appears as part of the Donath papers at the University of Pennsylvania. Helzel built a chapel, the Helzelkapelle, near Chotovice south of Nový Bor and owned a spa at Chotovice.

53 Leopold Janke et Cie was one of the most important Bohemian glass producers selling wares in the Atlantic world, see Klaus Weber, Deutsche Kaufleute im Atlantikhandel, 1680-1830: Unternehmen und Familien in Hamburg, Cádiz und Bordeaux, München 2004, p. 136; Josef Sieber, Zur Geschichte der Haidaer Glasindustrie: Was Geschäftsbücher erzählen, 1775-1825, Mitteilungen des Nordböhmischen Exkursions-Klubs 37, 1914, no. 4, p. 216-225.

54 LA PNP, Fr. S. A. Steinský, Donath to Steinský, 10 December 1794.

55 LA PNP, Fr. S. A. Steinský, Donath to Steinský, 10 December 1794 and 5 February 1795.

56 Free Library of Philadelphia, „Love Letter (Liebesbrief) for M. R. Donath,“Item no. frk01064. Available online via https://libwww.freelibrary.org/digital/item/6523 [last accessed 28/05/2021]

57 LA PNP, Fr. S. A. Steinský, Donath to Steinský, 5 February 1795. 
in 1829 after many years of a successful business and as the patriarch of a new American dynasty. The Donaths, along with members of the Koecker family, are buried today at the churchyard of Saint Mary's Church, a few blocks distant from Donath's original business in Philadelphia.

\section{The Donath-Steinský Correspondence 1790-1795}

Donath and Steinský exchanged at least eight letters between 1790 and 1795. This is clear from the mentions of other correspondence in existing letters. However, the total surviving correspondence between them amounts to five letters during this period. It is unlikely a trace of further letters survives given the scattering of Steinskýs archive and the poor record keeping on his behalf. As Donath once chided him, „you keep no account of your letters as we merchants mechanically do. ${ }^{\text {"58 }}$ All existing letters stem from Donath's hand. Four are contained within the Steinský collection at the Literary Archive in Prague and the remaining (earliest) letter from 1790 is found in the Archive of the National Museum in Prague..$^{59}$ Donath wrote three letters in English and two in French. All letters reflect the intimacy of their friendship given the presence of jocular insults and the shared interests of both men. It is also clear both men did favours for each other. Steinský monitored the interests of Donath's commercial connections in Bohemia such as the Janke family in Nový Bor. Donath, meanwhile, facilitated Steinskýs contacts with North America. His letter of 1790 mentioned an additional, but lost letter to Franklin likely written by Steinský at some point in 1789 which may not have reached Franklin before his death in April 1790. ${ }^{60}$ Taken as a corpus, the letters demonstrate the deep-rooted connections within the relatively small circle of individuals in Bohemia and Pennsylvania at the end of the eighteenth century.

Table 1 - Total Letters Exchanged between Donath and Steinský, 1790-95

\begin{tabular}{|l|l|l|l|l|l|l|}
\hline No. & Date & Author & Recipient & Origin & Date Received & Location \\
\hline 1 & $19 / 04 / 1790$ & Donath & Donath & Philadelphia & & ANM \\
\hline 2 & $17 / 06 / 1791$ & Donath & Steinský & Philadelphia & $26 / 07 / 1791$ & LA PNP \\
\hline 3 & $12 / 09 / 1791$ & Steinský & Donath & {$[$ Prague $]$} & s.d./03/1792 & Lost \\
\hline 4 & $20 / 07 / 1792$ & Donath & Steinský & Philadelphia & & LA PNP \\
\hline 5 & Ca. $07 / 1793$ & Donath & Steinský & {$[$ Philadelphia $]$} & & Lost \\
\hline 6 & $10 / 12 / 1794$ & Donath & Steinský & Philadelphia & $20 / 07 / 1794$ & LA PNP \\
\hline 7 & $03 / 06 / 1794$ & Steinský & Donath & [Prague] & $26 / 09 / 1794$ & Lost \\
\hline
\end{tabular}

${ }_{58}$ LA PNP, Fr. S. A. Steinský, Donath to Steinský, 20 July 1792.

59 A. Petráñová, Z korespondence, p. 112.

60 Archiv Národního muzea Praha (ANM), Fond Steinský, Donath to Steinský, 19 April 1790. 


\begin{tabular}{|l|l|l|l|l|l|l|}
\hline 8 & $05 / 02 / 1795$ & Donath & Steinský & Philadelphia & 20/07/1795 & LA PNP \\
\hline
\end{tabular}

$A N M=$ Archives of the National Museum, Prague $/ L A P N P=$ Literary Archives of the National Museum of Literature, Prague

The the correspondence of Donath and Steinský also has much to say about attitudes towards the pursuit of natural enquiry during the Enlightenment and the political divergences between America and Europe in the Age of Revolutions. This is reflected in the two predominant themes within the Donath-Steinský correspondence: science and politics.

Natural observations and scientific experiments were a continual feature of Steinskýs letters. In many ways, it seems Donath took over from Franklin as Steinskýs chief scientific correspondent in the United States. Questions about the temperature of the world's oceans preoccupied eighteenth-century minds, especially Franklin. In the 1760s, he attempted to chart the Gulf Stream for the first time with the help of New England whaling captains. During his multiple crossings of the Atlantic in later years, Franklin dropped thermometers into the ocean to record the temperature at different depths and at different longitudes when passing through the Stream's known location. ${ }^{61}$ Franklin's experiments at sea resonated with the emerging study of hydrography in the Habsburg Monarchy. The Jesuit Tobias Gruber (1744-1806), a close friend of both Steinský and Donath as well as member of the Bohemian Society of Sciences, led the field with explorations of cave water systems in Slovenia leading him to first postulate the concept of groundwater. ${ }^{62}$ His career as an architectural advisor for the construction of canals in Bohemia and in the Banat of Temeswar as well as navigation improvements on the Danube stimulated his research into the effects of temperature upon the qualities of water in terms of refraction and evaporation. He also devised better tools for measuring the surface temperature of water. Steinský informed both Donath and Franklin about his progress and through Donath forwarded Franklin copies of Gruber's scientific treatises on water in $1789 .{ }^{63}$ By this time Gruber had also become aware of Franklin's observation

61 Louis De Vorsey, Pioneer Charting of the Gulf Stream: The Contributions of Benjamin Franklin and William Gerard De Brahm, Imago Mundi 28, 1976, pp. 105-20; Ellen R. CoHn, Benjamin Franklin, Georges-Louis Le Rouge and the Franklin/Folger Chart of the Gulf Stream, Imago Mundi 52, 2000, pp. 124-142.

62 Trevor SHaw - Alenka Čuk, Slovene Karst and Caves in the Past, Ljubljana 2015, pp. 130-131.

63 Both Gruber's Physikalische Abhandlung über die Stralenbrechung und Abprellung auf erwärmten Flächen, Dresden 1787; IDEM, Versuche über die Ausdünstung des Wassers im leeren Raume des Barometers, Dresden 1789 appeared in Franklin's library, see Edwin Wolf - Kevin J. Hayes, The Library of Benjamin Franklin, Philadelphia 2006, p. 386. 
on the degree of the sun's reflection upon seawater and included this in his own work a few years later. ${ }^{64}$

In Donath's second short letter to Steinský sent on 17 June 1791 from Philadelphia, he reports solely on his experiments at sea during a recent voyage in the northern Atlantic. Donath detailed his findings that the temperature remained the same between the longitudes of $50^{\circ}$ to $70^{\circ} \mathrm{W}$ but noted how it increased during his crossing through the Gulf Stream. ${ }^{65} \mathrm{~A}$ broken thermometer foiled Donath in his experiment, however, which caused him to order a replacement from Steinský to be sent to him along with his next shipment of glassware from the Janke family. ${ }^{66}$ In fact, Donath requested specific instruments to be commissioned for him by Steinský and he wished to report on his findings directly to Gruber himself. ${ }^{67}$ By utilising his profession as a merchant and as a frequent traveller on the seas, Donath upheld the transatlantic Republic of Letters which emerged between Prague and Philadelphia in the late eighteenth century.

Political affairs remained a constant source of discussion within Donath's letters to Steinský. It was a source of friendly lampooning between them. Donath clearly enjoyed mocking Steinský in a jovial manner for what he saw as his support for a repressive monarchical regime. Already in his first surviving letter of 1790, Donath outlined his belief in the backwardness of the European states, especially the Habsburg Monarchy compared to the United States. He wanted the "flame of liberty" to raise among the people there and to free them from the decline into „despised slaves. "He felt France and the Low Countries were suitable models for the European reclamation of liberty, which he held to be more precious than life itself. ${ }^{68}$ His passionate appeal for the democratic progress of humanity was most apparent in the letter of 1792 presented below. In this letter, Donath again chastises Steinský for his role within monarchical society. „As a good subject and public professor, "he wrote, ,it is your duty to keep out every ray of light, and darken even darkness itself." But Donath reserved his most inciteful condemnation for the ruling classes, the aristocrats and rulers who fritter away their lives ,for the gratification of a number of fool" or who „squander away in luxury or prostitution." Rulers who did little for their people or who use the populace to wage war were the most condemnable in his mind. Indeed, though he advocated the general ferment against monarchism, Donath disparaged the effects when it resulted in war. He abhorred the outbreak of the French Revolutionary Wars in his correspondence with Steinský. There was an obvious motive

64 Tobias Gruber, Physikalische und oryktologische aus dem Riesengebirge gesammelte Bemerkungen, in: Johann Jirásek - Tobias Gruber - Tadeáš Haenke - František Josef Gerstner (edd.), Beobachtungen auf Reisen nach dem Riesengebirge, Dresden 1791, p. 267.

65 LA PNP, Fr. S. A. Steinský, Donath to Steinský, 17 June 1791.

66 LA PNP, Fr. S. A. Steinský, Donath to Steinský, 20 July 1792.

67 LA PNP, Fr. S. A. Steinský, Donath to Steinský, 10 December 1794.

68 ANM Praha, Fond Steinský, Donath to Steinský, 19 April 1790. 
for doing so, however; as a businessman trading between Central Europe and North America, he was losing money as ships struggled to safely make their crossings. ${ }^{69}$

Donath's harsh criticism of monarchy can be attributed to his new allegiance to the United States. His wealth and successful business seemingly turned him into a rabid republican. Donath excused his attacks on the aristocracy as the natural byproduct of his relocation and adoption of the American ethos. To speak one's mind freely, he asserted, was the "birthright of every American“ in a "happy hemisphere where the first-born sons of freedom dwell." Noting that Americans were the 'first' people to live in freedom, Donath advocated their revolutionary principles to extend to Europe as appeared to be the case in France. Yet, in espousing such enthusiasm Donath was not alone. In the 1790s, it was a normative worldview of the emerging democratic element within American society which took shape during the early $1790 s .{ }^{70}$ In this sense, Donath reflected the increasing polarization of American society between 'democrats' invested in the principles of the French Revolution even as it descended into terror and mayhem rather than see a return to oppressive monarchy, and those who supported neutrality vis-à-vis the French Revolution and even rapprochement with Great Britain instead. Typifying this outlook was Donath's unremitting assault on the figure of the monarch, in this case the heads of the Habsburg dynasty, whom he referred to in one instance as the „butcher of men."

Donath's pointed question to Steinsky of 'what animal is the emperor?' encapsulated this view further. His suggestion to have the progressive canon scholar Joseph Valentin Eybel (1741-1805) answer the question is noteworthy. Eybel published a provocative pamphlet entitled What is the Pope? at the time of Pope Pius VI's visit to Vienna in 1782 in response to the liberal religious reforms of Emperor Joseph II. ${ }^{71}$ Eybel's booklet decried the imposition of the pope, refuted the concept of papal primacy, and argued that his visit should be no more regarded than that of a simple bishop or clergyman. The controversy ignited around such suggestions ensured Eybel's work became ,the most famous and typical of all journalistic publications of the Josephist decade. " 72 Donath was clearly aware of Eybel and his work at the time. Indeed, his own questioning 'what animal is

69 LA PNP, Fr. S. A. Steinský, Donath to Steinský, 10 December 1794. Donath references his fears for the possible loss of a ship to St. Domingo.

70 Seth Cotlan, Languages of Democracy in America from the Revolution to the Election of 1800, in: Joanna Innes - Mark Philp, Re-Imaging Democracy in the Age of Revolutions: America, France, Britain, Ireland 1750-1850, Oxford 2013, pp. 13-27.

71 Franz A. J. Szabo -Antal SzÁntay - István György Töтн, Politics and Culture in the Age of Joseph II, Budapest 2005, pp. 61-62; Derek BeAles, Joseph II and the Monasteries of Austria and Hungary, in: Nigel Aston (ed.), Religious Change in Europe 1650-1914: Essays for John McManners, Oxford 1997, pp. 161-184, here p. 178.

72 Manfred Brandu, Der Kanonist Joseph Valentin Eybel (1741-1805): Sein Beitrag zur Aufklärung in Österreich. Eine Studie in Ideologie, Steyr 1976, p. 146. 
the emperor?' echoed of the famous Viennese poet Aloys Blumauer (1755-1798) who similarly reformulated Eybel's question when he published a review defending the pamphlet and criticising the scornful journalistic response to Eybel's important work. ${ }^{73}$ Blumauer, as a prominent freemason who moved in the same circles as Donath in Vienna, was surely a person who Donath knew and evidently admired. ${ }^{74}$ It is interesting, therefore, that Donath would recall such characters in his own dismantling of authority structures in a later point in the Age of Revolutions. The reusability of one context to another suggest a more unified approach between the Josephine reforms of the 1780s and the democratic march of American and French democrats in the 1790s. Besides being a rare example of a Central European reflecting on his former homeland from the New World, Donath's political outlook can reveal much more about the interconnectedness of these seemingly two disconnected spaces.

\section{Edition of the Letters of 19 April 1790 and 20 July 1792}

The following edition is a verbatim transcript of the original letters sent by Donath to Steinský in 1790 and 1792 from Philadelphia. The original spellings have been retained and additional data to the original is provided in [brackets] where necessary. Grammatical syntax has also been preserved as best as possible and errors in spelling or shorthand expressions are also explained with the use of sic. Crossed out words in the original are presented with a strikethrough. These crossings out by Donath are mostly still legible and were certainly readable by Steinský. It is highly probable Donath drew through these words to avoid censorship but whilst still conveying his critical remarks on monarchy.

\section{Letter 1:}

Archiv Národního muzea Praha, Fond Steinský, Donat Steinskému ze dne 19. 4. 1780.

\section{Mr Francis Steinsky}

Prague

Philadelphia April 19th 1790

Dearfriend,

I wrote you some time ago by the way of London to advise you my arrival in this city the beginning of October last, and that from the sickly state of health of Dr. Franklin, I could never find a opportunity of delivering the packet to him myself, and therefore had it handed to him by Mr. Smith Barton, a particular friend of his - but in all appearance too late to hope for an answer here below, for the justly celebrated patriot and Philosopher B. Franklin died last night

73 IвIDEM, pp.174-175.

74 Franz M. Eybl - Johannes Frimmel - Wynfrid Kriegleder (edd.), Aloys Blumauer und seine Zeit, Bochum 2007. 
and will be interred after tomorrow, so that the Prague Panegyrist may with more propriety say over again his funeral oration, and I do not doubt but reality may make it better.

I have been too busy to write you more frequently and indeed what should I write to you, of Politicks? I question whether you expect this from, for subjects to a despot should be quite ignorant as they are deprived of civil liberty, lest they feel the yoke and accustomed chains by comparison, and grow more unhappy, than they deserve to be. However I do not mean that my countrymen should be forever doomed to be nothing more than despicable vassals, no my friend, I sincerely wish that the flame of liberty may spread among them, and restore to them to the natural right of man - but I am afraid it is too soon for the common people have been kept too long in darkness, and it will require some time before they can be brought to a just sense of their right, and a determining desire to assert and hold it dearer than life. In former days, the light spread from the east, but of late it shone brighter from the west. France and the A. Netherlands have been illumined, and from the happy effects it will produce, it cannot fail of being courted successively by all the nations of the globe.

Our union has been lately strengthened by the accession of North Carolina to the federal government, which meets with general approbation from the happy effects resulting from it. Rhode island will come in one day or other, and then let the envious English and after them the german scriblers [sic] talk of american anarchy as much as they please.

But to another topic of our frequent conversation - marriage. I hope that by this time your indecision has given way to the choice of one of the worthy objects you had in view and from this persuasion I wish you as much happiness, as this state is capable of. I must own that I am very curious to know, which of them you have made the partner of your life and from my own feelings, I am apt to imagine that your affections will have concentered [sic] somewhere not an hundred miles from St. Thomas - at least I heartily wish it, for you could not have entered in a more respectable and worthy family, whom on joint account I shall hold dear all the days of my life. As for poor myself, I have abandoned all Ideas of such a connexion, and I am sure that all your persuasive Rhetoric will be ineffectual with me, not from a want of social disposition, but from the wandering condition, and the advanced days of my life. For I propose to make another trip to Europe next autumn, where I shall have the pleasure of seeing you and your friends again. Therefore it will be needless to answer this letter.

I have not forgot Mr. Abbé Gruber, but a, actually copying at leisure hours the ob meteorological observations of the year 1787, 1788, and part of 1789, where they have been discontinued by my friend, owing to his frequent avocations. I have begun a new from January last, and he shall have the whole on my arrival, to which time I recommend him the salutary virtue of patience. I hope he will have furnished my brother with instruments, as I requested it, as in that quarter there have never been any observations made.

I was not a little surprised to hear that Messrs. Kohler Kehrn Hg are dissolving partnership and give up business; from what motive, I cannot comprehend. It is however lucky, that I left them before, or I would have been greatly embarrassed. 
Recommend me kindly to all our friends particularly where I was mostly charmed, and where you did not solely peep at the moon. To the amiable family, corner of St. Nicolas Church you may tell besides, that the sarsaparilla growing in this country is of an inferior quality to that of the Spanish islands, therefore to send none, as also of the Jesuits bark, which I found too dear.

I cordially embrace you and shall ever be, Your affectionate friend,

[Cover: a Monsieur // Monsieur François Steinsky // a Prague // En Boheme]

Joseph Donath

\section{Letter 2:}

Literární archiv Památníku národního písemnictví, Fr. S. A. Steinský (1760-1811), Donath to Steinský, 20 July 1792.

Philadelphia 20 July 1792

Dearfriend,

I received your friendly letter of the 12th of Sept. sometime in March. I write you in July and hope it will come to hand before the expiration of a twelve month, therefore if we go on in this manner, neither of us will have much reason to complain of extravagant postage. I perceive that you keep no account of your letters, as we merchants mechanically do, undoubtedly because you think them of little consequence, and this may perhaps be the very reason of your tardy answers, which I cannot but retaliate. I see however with pleasure that you have made up the loss, for I was very curious to know the issue of the adventure, I was so unhappily concerned in. I am indeed glad it has turned out as it did, for the young man in his wild imagination sharpened by repeated and alternate refusals and hopes had conceived too high and romantic ideas of America, and of course would have found himself disappointed both to his mortification, and that of his parents, and who would have suffered the blame but myself. Independent of which he would at all events have been a heavy charge to me. By the last vessel, I was very much surprised to find a letter of his inclosed [sic] in one of my correspondents in Rumburg [now Rumburk near Děčin], in which he tells me, that maugre all obstacles opposed to him, he had dared to devote himself to commerce, and would have joined me this year yet, if he had not been kept back by fair promises of accomplishing his object by a surer tho' later means. This entirely corroborates my above opinion, but engaged as he is now in his new course I warrant he will have a fair opportunity of forming his judgement by experience and correct the wild illusions of a heated imagination. You may if you chuse [sic], translate these observations to his parents, whom I cannot but esteem for their tender concern they took of their child in at least a doubtful enterprise. 
Now to the second part of your letter, which concerns your nearer home. I am fully convinced, that by your picking and chusing [sic] and refusing, you will be brought at last to put up with a crooked stick, or get none at all to support you with, this I am persuaded is the plain truth, and I long to hear you decided one way or the other. As to myself, I am passed the time, and in case of need une menagerie will do, you approach very fast the same period, or rather you are very near it. Therefore take heed and warning from a friend that sincerely loves and esteems you. What you tell of the late E... [Emperor Leopold II], I clearly see, that you did it in all the enthusiasm of a heated fancy blinded by pageantry and prejudices and flattered by ambition, and in this disposition you would have done exceedingly well for a court mongrel. Pardon me this expression, a friend t [a]ught to speak his mind freely, and this is the birthright of every American. You lay so much stress upon his addressing you with what d'ye [sic] want. I an sec nothing improved in this vulgar expression and in the whole I take him to have been rather dissembling hippocr. [hypocrite] than a true demoor [demur]. You speak high of his generosity in throwing away $200 \mathrm{f}$ mostly the bloody earning of the poor or a daring foot who express bis tife to no purpose in an air battoon, merely for the gratification of a number of foots and then populas in pace aegebat [?] after the most informat combination with the K[ing] of P[russia] to keep up the detest imposition of sacrum jus regum in horrid defance of the originat rights of man, verity may I say of my poor countrymen, what is generally said of thorses, that they do not know their fore or etse they wo riden. Ignorance therefore is the only bulwark of despotism, and as a good subject and public professor it is your duty to keep out every ray of light, and darken even darkness itself.

What other enchanting scenes in this happy hemisphere, where the first-born sons of freedom dwell, peaceably assembling to consult about their own weal, not raise miltions for one man to squander away in luxury or prostitution, or enable him to destroy thousands of his fellow trates and acquire by such heroic deeds, the ever glorious appellation of Conqueror, or in plain English, butcher of men.

But that you may not retaliate and charge me with enthusiasm on the other side of the question, I will put a stop to the effusions of my heart patiently waiting for your answer, perhaps another coronation may suggest new ideas of the divine rights of kings.

Pray let me know, whether Mr Eibel [sic: Eybel] is yet alive? He has heretofore so masterly handled the question, what is the pope? $?^{75}$ I want to propose to him the question: what animal is the emperor, and what is coronation? I am sure there is nobody in all the imperial dominions so able as Mr. Eibel [sic] to define and elucidate it. If perchance he should be dead, please to send the queries to France, where it is said, the sun has rose form the west. As to my meteorological observations, I know no other method of receiving them with any degree of safety, than by your sending them with a fair opportunity to Mr. Joh. Wenzel Janke in Langenau near Hayda [sic] requesting him to pack them in a case. As I order no goods from Prague, and will have done

75 Joseph Valentin Eyвel, Was ist der Pabst?, Wien 1782 (translated into French as IDEM, Qu'est-ce que le Pape?, s.1. 1783). 
entirely with Thum's Heirs [sic]. Pray give my respects to Abbé Gruber, and Blümel, and if you write me within a few days after the receipt of this letter per address of Messrs. Vandersmissen Sons in Altona, you may be sure of my receiving your answer with the return of the vessel, that carries you this. I am sincerely,

Your affectionate friend Jos. Donath

[Cover: A Monsieur // Monsieur Fr. Steinsky, Prague // per. addris van UE [Dutch honorific] L W Dienaar // Tjalling Visser // per Capt. James Dreijburg // van Philadelphia] 
Jonathan Singerton

\section{Science, Revolution, and Monarchy in Two Letters of Joseph Donath to František Antonín Steinský}

\section{Abstract}

Two letters from the surviving eighteenth-century correspondence between the polymath professor of history František Antonín Steinský in Prague and his friend, the merchant Joseph Donath in Philadelphia reveal an interesting episode in the transatlantic connections between Central Europe and North America. On the one hand, Donath's scientific observations conducted on behalf of Steinský and his associates reveal the shared enlightened pursuits between both regions, while on the other hand, Donath's scorn for the perceived political backwardness of his former compatriots reflect the widening divide ushered in by the Age of Revolutions. Alongside the first biographical accounts of both Donath and Steinský in English, this article presents for the first time a full transcription of two letters sent from Philadelphia to Prague in the 1790s. It explores the role of science and political discussion within their friendship across the Atlantic and contributes towards unearthing the wider interplay of interpersonal relationships between two different socio-political systems, namely a monarchy and republic.

KEYWORDS:

Edition; Archival; Letters; Transatlantic; Enlightenment; Age of Revolutions; Early America; Central Europe; Habsburg Monarchy. 